\title{
Implementation of the National Early Warning Score Tool in the Acute Care Setting
}

Amanda Reyes

University of St. Augustine for Health Sciences, a.reyes1@usa.edu

DOI: https://doi.org/10.46409/sr.HIWI1753

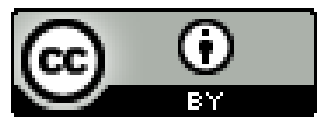

This work is licensed under a Creative Commons Attribution 4.0 License.

Follow this and additional works at: https://soar.usa.edu/scholprojects

Part of the Critical Care Nursing Commons, Other Nursing Commons, and the Quality Improvement Commons

\section{Recommended Citation}

Reyes, A. (2021). Implementation of the National Early Warning Score Tool in the Acute Care Setting. [Doctoral project, University of St Augustine for Health Sciences]. SOAR @ USA: Student Scholarly Projects Collection. https://doi.org/10.46409/sr.HIWI1753

This Scholarly Project is brought to you for free and open access by the Student Research at SOAR @ USA. It has been accepted for inclusion in Student Scholarly Projects by an authorized administrator of SOAR @ USA. For more information, please contact soar@usa.edu, erobinson@usa.edu. 
Implementation of the National Early Warning Score Tool in the Acute Care Setting Amanda Reyes MSN, RN

School of Nursing, University of St. Augustine for Health Sciences

This Manuscript Partially Fulfills the Requirements for the

Doctor of Nursing Practice Program and is Approved by:

Theresa M. Pape, PhD, RN, CNOR-E, CNE

Dr. Tina Neu, DNP, FNP, NE-BC, CNOR

August 02, 2021 


\begin{abstract}
Practice Problem: The organization arbitrarily called a rapid response or code blue call based on abnormal vital signs or intuition and needed a new process to identify early recognition of patient deterioration.

PICOT: For adult inpatients in an acute care setting in a large healthcare system $(\mathrm{P})$, will implementation of the National Early Warning Score (NEWS) across the organization (I) compared to data from the last fiscal year where NEWS was not used (C) decrease code blue calls $(\mathrm{O})$ within 8-weeks $(\mathrm{T})$ ?
\end{abstract}

Evidence: Eleven high quality studies met the inclusion criteria and found that the NEWS is a validated track and trigger tool, which promotes early detection of patients' clinical deterioration and more accurate rapid response calls.

Intervention: Staff fulfilled virtual training on completion of the NEWS tool within the computerized patient record system. Chart audits were conducted to measure compliance with the number of times the NEWS tool was used to trigger an event, and the number of times the trigger was missed.

Outcome: The result of the two-tailed paired samples t-test was not statistically significant for rapid response calls. However, the clinical significance of NEWS implementation was that there was an increase in rapid responses and a decrease in code blue responses post NEWS implementation.

Conclusion: The NEWS tool provided accurate identification of clinical deterioration to improve patient outcomes. 


\section{Implementation of the National Early Warning Score Tool in the Acute Care Setting}

The standard of care in the United States is to place patients with clinically significant changes in the acute care setting for monitoring (Academy of Medical-Surgical Nurses, 2020). The incidents when clinically significant changes are missed on acute care units have caused concerns for patient safety (Barwise et al., 2016). Several factors impact the ability of nurses to make rapid clinical decisions on when and how to intervene when a patient is deteriorating (Nibbelink \& Brewer, 2018). The purpose of this project is to implement a track and trigger tool to help providers make clinical decisions through defined escalation points, based on physiologic parameters, in order to standardize recognition of potential precursors to an untoward event (Patel et al., 2011).

\section{Significance of the Practice Problem}

In the United States (U.S.), preventable deaths of hospitalized patients are estimated to be nearly 100,000 annually. Cardiopulmonary arrest is one of the most common types of preventable deaths highlighted by the Institute of Medicine (2000). According to the American Heart Association's “Get with The Guidelines Resuscitation Registry” (GWTG-R), in-hospital cardiac arrests were estimated to be between 200,000 to 300,000 per year in the U.S. (Andersen et al., 2019). This translates to approximately 10 arrests per 1,000 admissions in the U.S. compared to 1.6 arrest per 1,000 admissions in the United Kingdom (U.K.) (Anderson et al., 2019). Survival rates of in-hospital arrests remain low but vary significantly between hospitals and range from $11 \%$ to $37 \%$ (Chan et al., 2016; Holmberg et al., 2019).

Rapid Response Teams (RRTs) have become a standard of practice to improve early intervention for patients with declining conditions in the hospital (Allen et al., 2017). The success of RRTs in reducing mortality have been inconsistent (Chan et al., 2016). Although 
RRTs are available, avoidance of delays in early identification of deterioration is vital to improve survival. Acute patient deterioration can lead to unexpected intensive care unit transfer, cardiac arrest, or death (Ahn et al., 2020). Barwise et al., (2016) found that delays greater than 1 hour in triggering an RRT increased length of stay and 30-day mortality rates by $7 \%$.

Within a large healthcare system in California, during the fiscal year (FY) 2020, a total of 79 code blue calls occurred. There were 268 rapid response calls for fiscal year 2020 . The hospital nursing staff often call code blues and rapid responses arbitrarily based on irregular vital signs, observation of patient's clinical presentation, or on their intuition. According to the Royal College of Physicians (2012) the utilization of a track and trigger tool can aid in determining when to calling a rapid response or code blue.

\section{PICOT Question}

According to The Joint Commission (2020), the zero-harm principle stipulates that a healthcare organization should implement processes to eliminate preventable harm. And as healthcare organizations today strive to become high reliability organizations (HRO), standards of care are established towards pursuing the zero-harm principle. Mitigating failure to rescue in hospitals is one step towards becoming an HRO.

For this project then, the PICOT question is: For adult inpatients in an acute care setting in a large healthcare system $(\mathrm{P})$, will implementation of the National Early Warning Score (NEWS) across the organization (I) compared to data from the last fiscal year in which NEWS was not used (C) decrease code blue calls (O) within 8-weeks (T)?

\section{Population}

The population represents primarily adult patients on the acute care unit. The acute care units for project execution include three medical surgical units, one definitive observation unit, 
one intensive care unit, three spinal cord injury units, and one acute rehabilitation unit. This project was implemented in one hospital of a large healthcare system which is licensed to operate 110 beds.

\section{Intervention}

The intervention involved the implementation of the NEWS as part of a daily nursing assessment. The NEWS is a track and trigger validated tool that scores six physiological measurements that are being monitored for acute care patients. The six measurements of the NEWS include respiratory rate, oxygen saturation, temperature, systolic blood pressure, pulse rate, and level of consciousness (Royal College of Physicians, 2012).

\section{Comparison}

The hospital organization used for this change project has never used a track and trigger tool to score physiological parameters. Thus, comparison is based on historical data from the last fiscal year when NEWS was not used. The NEWS improves assessment of acute illness, detection of clinical deterioration, and initiation of a timely clinical response (Royal College of Physicians, 2012).

\section{Outcome and Timeframe}

The anticipated outcome was a decrease in hospital code blue calls. The NEWS was implemented for 8-weeks in nine acute care wards. Consistent chart audits and feedback were used during this time to support the intervention's success. Continuous communication by the project manager (PM) (DNP student) with the care providers was completed to further reinforce the execution of NEWS as well as compliance with its use.

\section{Evidence-Based Practice Framework and Change Theory}


The John Hopkins nursing evidence-based practice (JHNEBP) framework guided the development and implementation of the NEWS. Dang and Dearholt (2017) recommend the John Hopkin's framework to locate research findings to immediately identify and implement best practices. The JHNEBP framework involves a three-step process called PET: practice, evidence, and translation. The practice portion of the model involves the problem identifies within the hospital with lack of a method to improve early intervention for patients with declining conditions in the hospital. The evidence includes locating and refining the evidence-based practice question. The literature search and evidence table (Appendix A) demonstrated that the use of NEWS practices improve patient care outcomes through practice change. The final stage of translation involved the implementation of the project plan and evaluation of the outcomes.

\section{The ADKAR Change Theory}

The awareness, desire, knowledge, ability, and reinforcement (ADKAR) change theory was used to guide the implementation of the NEWS project. This healthcare organization already utilizes the ADKAR as their change theory management approach making the change method process more agreeable to staff. There are five stages that comprise ADKAR. The opening stage of the change theory is awareness. Desire is the second stage that involves appealing to the logical and emotional side of employees. The third step is the knowledge goal, with ability as the fourth step of the ADKAR. The final stage of ADKAR change theory is reinforcement (Prosci, n.d.).

The project application of the ADKAR model begins with the awareness stage in ensuring that the hospital providers understand the need for change. With knowledge gained from the literature review, evidence was provided to persuade frontline staff that a change was needed to improve the current situation. The PM drove desire by promoting the NEWS change 
benefits based on evidence-based practice. Real world examples of how NEWS has affected other hospitals drove providers desires towards implementation. The knowledge stage took place when the implementation plan started, and everyone's roles and responsibilities were clearly defined. During the knowledge stage, the timeline for implementation was set and deployed. Ability refers to the actual application of completing the assignment. The ability stage included supporting providers and nurses in the method to undertake the routine measurements of the NEWS score. During the reinforcement stage, assurance of maintaining the NEWS through the use of incentives or rewards were used until the intended process change became the new normal. The reinforcement stage of the NEWS was completed by sharing the success stories associated with positive patient outcomes.

\section{Evidence Search Strategy}

An exhaustive search was conducted using Cumulative Index to Nursing and Allied Health (CINAHL), Medline, OVID and the Cochrane Library. The keywords used in the search process include early warning signs, national early warning score, rapid response, deterioration, cardiopulmonary arrest, nursing implementation, and medical emergency team. The Boolean expression of ("national early warning scores" or "early warning signs" or "early warning score" or "NEWS”) AND (“deterioration” or "cardiac arrest” or "cardiopulmonary arrest”) AND ("implementation" or "nursing implementation") were used. The search limited the report-type to academic journals, English language publications, and a time frame of January 2015 to present date. Articles were screened to verify that they were peer-reviewed, used the NEWS and excluded NEWS-2 research at this time. Next, secondary sources and summary articles were excluded. The final literature review included a thorough evaluation and comparison of 11 articles to identify evidence-based interventions in the use of a track-and-trigger tool. A 
summary of primary resources including findings using a track-and-trigger tool, specifically the NEWS tool are shown in Appendix A.

\section{Evidence Search Results}

The online article search resulted in 40 from CINAHL, 28 from PubMed, 37 from Medline, 32 from OVID, and 20 from the Cochrane Library for a total of 157 records, which were reduced when duplicate articles were excluded. Also, articles that focused solely on the National Early Warning Score-2 (NEWS-2) or Modified Early Warning Score (MEWS) from which the NEWS was adapted, were excluded. The remaining 11 articles were reviewed for level and quality by using the JHNEBP level and quality guide. The remaining articles included a combination of seven that were of high quality, three good quality, and one low quality. The breakdown of levels included seven level I high quality, two level I good quality, one level II good quality, and one level I low quality (Figure 1). Systemic reviews were not found. The quality and level of the supportive literature were adequate to support this level I practice change recommendation.

\section{Themes with Practice Recommendations}

The literature produced three common themes: interprofessional collaboration, early detection of patient deterioration, and reliability of NEWS implementation.

\section{Interprofessional Collaboration}

A trend identified in the literature was the importance of interprofessional collaboration among nurses and physicians. Mismanaged patient deterioration is the most common cause of patient safety associated deaths. The NEWS promotes interprofessional collaboration by refining a communication tool across healthcare settings for a smoother patient handoff (Pimentel et al. 2019). The purpose of the NEWS is for nurses to observe and judge patients' conditions 
objectively and rapidly relay critical vital signs to providers (Tan et al., 2019). Physicians as well must swiftly identify and assess the severity of their patients' conditions in order to provide immediate care (Tan et al., 2019; Pimentel et al. 2019).

\section{Early Detection of Patient Deterioration}

The literature confirms the use of NEWS as an easy tool for early detection of patient deterioration and has reduced in-hospital cardiac arrests (Bartkowiak et al, 2019; Lee et al., 2018). The predictor measurements the NEWS delivers for in-hospital mortality is undeniable and has shown to lead to an increase in RRT arrivals that improve patients' outcomes (Lee et al., 2018). Use of NEWS presents the initial information for patient stabilization and prevents further deterioration. Shift reassessments using NEWS throughout the hospitalization enable objective follow-up (Kivipuro et al., 2018).

\section{Reliability of NEWS}

The efficacy of the NEWS track and trigger tool has led to the widespread adoption by healthcare organizations worldwide. The NEWS was effective for predicting hospital mortality with a 95\% confidence interval (Lee et al., 2019). Internationally, the NEWS has become a standard of care by providing a common language in communicating deterioration of patients' hospitalization (Pimentel et al., 2019). The Kaplan Meier survival curve showed patients who scored high on the NEWS had a significant shorter survival time that those who had low NEWS scores (Lee et al., 2019). As a result of implementation, this clinical decision-making tool has increased RRT calls, and decreased code blue calls (Lee et al., 2019; Silcock et al., 2018;

Tirkkonen et al., 2019).

\section{Practice Recommendations}


A thorough review of the literature answered the PICOT question by establishing the NEWS tool as an appropriate implementation project to alert providers of early clinical deterioration thereby increasing RRT calls and decreasing code blue calls. The JHNEBP support this practice change. Based on the themes drawn from the synthesis of evidence, interdisciplinary collaboration and implementation of the NEWS leads to optimal patient outcomes. Collaboration with the acute care staff will continue to ensure successful understanding of the NEWS as it becomes part of routine practice.

\section{Project Setting}

The setting for this project was a large diversified tertiary highly complex health care system. This health care system delivers comprehensive inpatient, outpatient, and extended care to patients in the surrounding area. The hospital employs over 2,200 full-time employees and services over 50,000 patients in the area. The typical patients are seeking healthcare services in cardiovascular, bariatric, emergency, blind rehab, spinal cord injury, and traumatic brain injury care. This project solely focused on implementation within the acute care setting. There are nine acute care units for this facility.

The organizational structure includes the medical center director, chief of staff, associate director of patient care services, deputy associate director of patient care services, and two assistant directors. The next level includes department service chiefs and managers followed by direct care staff in each department.

\section{Organizational Needs Assessment and Support}

A national needs assessment was completed for this project. The implementation of a track and trigger tool was suggested for all 170 hospital sites. A needs assessment and gap 
analysis were completed for this specific organization. In moving towards becoming an HRO, the need to decrease mortality rate assists the organization with this endeavor.

Support from stakeholders within the healthcare system include the executive leadership team. These include: the medical center director, chief of staff, associate director of patient care services, and deputy associate director of patient care services. Support from the department of quality, safety \& value (QSV) was important to ensure the NEWS implementation meets all surveying requirements and hospital protocols. The informatics department (IT) and computerized patient records system (CPRS) department were essential to evaluate the NEWS scale. The nursing leadership council, nursing professional practice council, and resuscitation management committee (RMC) support this system wide change. The education department had an interest of assuring that providers understand the NEWS scales. The organization's physicians supported the need for a track and trigger tool. Other stakeholders included nurse managers, nurses, nursing supervisors, patients and patients' family members.

A strengths, weakness, opportunity, and threat (SWOT) analysis was completed in order to assess the hospital's readiness for implementing change. Key strengths include national and local leadership support. The hospital system representatives have made it known that they support the NEWS implementation as their track and trigger tool of choice. Other strengths include a robust education, QSV, and IT departments. The primary weakness was lack of computer labs for training. External threats included a risk of COVID-19 surge that could place all new hospital wide systems changes on hold, increased in unplanned employee leave, and staff turnover.

\section{Project Overview}


The primary aim of this project is to decrease code blue calls by using the NEWS. Nurses will need to escalate care using the NEWS tool beginning March 2021. The short-term objectives of this project include the following:

1. That $95 \%$ of providers and nurses will be using the NEWS tool within one month.

2. Eighty percent of acute care patients will have a charted NEWS score in one month.

3. All of the CPRS chart audits completed to identify potential barriers in NEWS implementation within one month.

Long term objectives include:

1. All of acute care patients will have a documented NEWS score within two months.

2. One hundred percent of nursing staff will use the NEWS tool in two months

\section{Implementation of Change}

The ADKAR change theory was used to safeguard sustainability. Ensuring stakeholders involvement, acknowledging everyone's efforts, and sharing positive lessons learned as recommended by the West of England Academic Health Science Network (2016). Sustainability of the NEWS template was supported by the IT department by the creation of a documentation field within the computerized patient record system (CPRS). Training materials were incorporated within the new employee orientation. A repeatable module was created in collaboration with the nursing service department. These modules were assigned as needed. The associate director of patient care services ensured implementation was sustained. Updates on the NEWS changes were provided during daily data management systems (DMS) huddle boards throughout the facility.

The nursing informatics team was responsible for template insertion into nursing documentation. The correct template assignment was manually verified by auditing the CPRS 
charting system. Due to social distancing measures as a result of the current pandemic, the nursing service department virtually trained employees via the Elsevier Clinical Skills Program (ECSP). A computerized module was assigned to all staff members as needed. The ECSP can generate reports to show training compliance and completeness.

Interprofessional collaboration improved with awareness and effective communication that helped drive the organizational change. Stakeholders needed to know why a change was happening. Building awareness began with providing the rationale and evidence for the project to the nursing leadership council and nursing shared governance committee. The IT department created the tool and embed the template into CPRS. Nursing supervisors were pivotal in determining bed assignments to ease patient flow. When escalation in level of care were warranted for patients based on their NEWS score, the Nursing supervisors ensured proper bed assignments. The facility encouraged the use of the NEWS tool to continue building collaborative relationships among different service lines to improve patients' outcomes.

\section{Protection of Human Participants and Privacy}

To ensure the protection of human participants, approval from the Evidence Based Practice Project Review Council from the University of St. Augustine School of Health Sciences, and from the IRB from the participating facility before beginning the project. There was minimal risk to participants inherent in this evidence-based practice project. Risks included that providers and

nurses could feel anxious at performing with the new process, or anxiety due to perceived lack of knowledge. Access to the specific electronic files required authentication, which provided for confidentiality of information. Patient's protected health information was not included in data collection. All data was stored on the participating hospital's main network, which required a personal employee identification card as well as an employee pin for access. Files were only 
accessible through a hospital-based password protected computer. There were no financial incentives for participant involvement in this project.

\section{Protection of Human Participants and Privacy}

The project did not begin until all approvals were received by the Evidence Based Practice Project Review Council (EPRC) and then by the Investigational Review Board (IRB) of the organization.

\section{Timeline and Budget}

The project was completed within the planned 8-weeks (Appendix C). The PM was responsible for maintaining the hospital's standards of practice regarding NEWS and working with the stakeholders toward the practice change. Key qualities of the PM included good communication skills, ability to work well with others, timeliness, and effective management. Information about the process was provided to all involved. Chart audits with feedback and any remedial training began immediately to ensure that just-in-time actions and problem resolution for any potential negative outcomes occurred.

The total cost for project implementation was approximately $\$ 6,700.00$ (Table 1). The NEWS tool was free and open access to the public. A limited budget for staff education and training was incorporated within the staffing plan, which is reviewed on an annual basis. There were no benefits for participation in the project.

\section{Results}

The impact of the NEWS on early recognition of clinical deterioration was determined through a pre- and post-intervention plan. The measures include the number of times the tool was used to trigger an event as well as the number of times the triggers were missed.

\section{Data Collection}


Data were collected for the 8-week period after the initial implementation of the NEWS intervention. Face validity of data collection tools (Appendix D) was established by review from nursing experts in which $100 \%$ agreed to all constructs of the data collection tools and deemed them valid for this project. Data were collected through chart reviews via the CPRS which aggregated the reports. Implementation compliance was generated via the facility's ECSP.

\section{Process Measures}

Numbers related to RRT and cardiac arrests were collected through reports from the resuscitation committee. The IT department personnel generated the reports of number of RRT, cardiac arrest, and NEWS scores for the resuscitation committee. The process metrics included the tallies of staff utilizing the NEWS tool and compliance with NEWS documentation. The PM monitored the process measures three times a week by manually conducting random audits of the nurses' documentation through CPRS. Any variances in the accuracy of documentation were further investigated to determine the root cause of the variances. To determine the short-term outcomes, compliance training reports were collected to observe if $95 \%$ of providers and nurses completed the NEWS tool. CPRS reviews were done to ensure a score of at least $80 \%$ of acute care patients. Percentages of completeness of use of the NEWS tool will be used in order to maintain compliance and sustainability.

\section{Outcome Measures}

The primary outcome measures were expressed in the number of RRTs and code events that occur in the acute care setting. To establish the relationship between the intervention and outcomes, code blue calls before and after the implementation of the NEWS tool were evaluated. Another outcome metric is the number of patients whose care was escalated due to a trigger 
initiated by an elevated NEWS score. The data was collected by the project manager using reports from the IT department.

\section{Statistical Analysis}

Using the statistical software program Intellectus, a two-tailed samples t-test was completed to determine if there is a significant difference between the number of pre vs. post rapid responses and pre vs. post code blue calls before and after the NEWS implementation intervention.

A Shapiro-Wilk test determined the difference of pre vs. post code blue calls and rapid response calls that could have been produced by a normal distribution (Razali \& Wah, 2011). The results of the Shapiro-Wil test were not significant based on an alpha value of $0.05, \mathrm{~W}=$ $0.94, \mathrm{p}=.425$ for code blue calls and an alpha value of $0.05, \mathrm{~W}=0.91, \mathrm{p}=.114$ for rapid response calls. This indicate that there was a normal distribution. The Levine's was not significant based on an alpha value of $0.05, \mathrm{~F}(1,28)=0.73, \mathrm{p}=.401$ for pre/post code blue calls and an alpha value of $0.05, \mathrm{~F}(1,28)=0.06, \mathrm{p}=.804$ for pre/post rapid response calls . This means that the distributions had equal variances, indicating the assumption of homogeneity of variance were met. However, the results of the two-tailed paired samples $t$-test were not significant based on an alpha of $0.05, t(14)=0.54, p=.595$ for code blue calls and an alpha of $0.05, \mathrm{t}(14)=-1.51, \mathrm{p}=.154$ for rapid response calls (Table 3 ). Nevertheless, a bar graph represents the clinical significance of NEWS implementation (Figure 3), showing that the number of code blue calls pre and post intervention decreased. There was an increase in RRTs and a decrease in code blue responses post NEWS implementation indicating success of the use of NEWS. 
The difference in the mean of rapid response calls before the intervention compared to the mean after the intervention of rapid responses pre and the mean of number of rapid response post intervention was not significantly different from zero (Table 4). A bar graph of the means is presented in Figure 4. Again, the bar graph illustrates an increase in rapid responses post implementation indicating success of the intervention. Clinically, staff are using the NEWS tool in recognizing patient deterioration sooner. These successes demonstrated that the clinical staff were able to recognize patient deterioration sooner as a result of the NEWS intervention. Descriptive statistics compared NEWS score with the calling of a rapid response (Appendix D; Table 5). For rapid response, $88 \%(n=65) \mathrm{t}$ of participants responded appropriately in calling for a rapid response team. For code blue, 97\% $(n=33)$ of participants responded appropriately in calling for a code blue.

\section{Impact}

The data collected from this evidenced based practice project support the expected outcome of using the NEWS track and trigger tool to decrease code blue calls. The NEWS tool helped providers recognize signs of clinical deterioration earlier than prior to the project implementation. The implementation has far reaching importance for other organizations who have a similar issue. Because the NEWS tool was embedded into provider charting, 95\% of providers and nurses have been using the NEWS tool in the first month. One hundred percent of acute care patients were shown to have a NEWS score in their CPRS profile. By recognizing signs and symptoms of clinical worsening sooner, patients are treated faster. NEWS implementation strengthens interprofessional collaboration by improving communication between nurses and physicians and improves patient care. Furthermore, prompt recognition of patient deterioration leads to positive patient outcomes by decreasing chances of mortality. 


\section{Dissemination Plan}

To disseminate the project's results, all data collected was presented to the RMC committee within the practice site and are now included as part of the standing committee agenda for this organization. This action assists in maintaining sustainability of the NEWS implementation over time. Project outcomes were shared during DMS huddle board updates at the unit level. The data management system boards are used for frontline staff communication.

Results of the project were presented virtually during the nursing leadership committee (NLC) via slide presentation. The associate director of patient care services, deputy nurse executive, chief nurses, nurse managers, and nursing supervisors were in attendance during NLC. Results were also shared with the quality, QSV department, as well as with the resuscitation committee. The resuscitation committee includes the chief of staff, deputy chief of QSV, attending chief physician from the emergency department, the hospitalist, the attending anesthesiologist, representation for pharmacy, respiratory therapy, and the nocturnist. A manuscript of submission will be sent to the Journal of Nursing Care Quality because of its strong focus on nursing leadership using evidence-based practices for improving care. As a requirement of the DNP project, this paper will also be submitted to The Scholarship and Open Access Repository (SOAR) for the University of St. Augustine for Health Sciences. SOAR collects and disseminates students' scholarly work in order to promote global discoverability. A final dissemination method of submission will be the submission to Sigma Theta Tau International repository to encourage open peer review and worldwide distribution.

\section{Conclusion}

Within a large healthcare system in California, there was a problem with healthcare providers response to patient deterioration. In the past nurses arbitrarily called rapid responses 
and code blue calls without use of a validated tool. The John Hopkin's Evidence based practice framework was used to complete this evidence-based project. The ADKAR theory was used as the change model for project implementation. This project implemented the NEWS as the validated track and trigger tool of choice. By implementing the NEWS track and trigger tool, nurses have been able to more objectively escalate patient care concerns to providers. The success of the project was measured by an increase in rapid response calls and a decrease in code blue calls within the acute care setting. The project outcome demonstrated that providers' early recognition of patient deterioration were now based on the NEWS score. Even though the results determined no statistical significance was found, clinical significance for this project is important. This evidenced based practice project supports the consistent use of the NEWS track and trigger tool to decrease code blue calls, thus improving patient care. 


\section{References}

Academy of Medical-Surgical Nurses. (2020). What is med-surg nursing? https://www.amsn. org/about-amsn/what-med-surg-nursing

Ahn, J., Jung, Y., Lee, J.-R., Oh, Y., Oh, D., Huh, J., Lim, C.-M., Koh, Y., \& Hong, S.-B. (2020). Predictive powers of the modified early warning score and the national early warning score in general ward patients who activated the medical emergency team. PLOS ONE, 15(5), e0233078. https://doi.org/10.1371/journal.pone.0233078

Allen, E., Elliott, D., \& Jackson, D. (2017). Recognising and responding to in-hospital clinical deterioration: An integrative review of interprofessional practice issues. Journal of Clinical Nursing, 26(23-24), 3990-4012. https://doi.org/10.1111/jocn.13839

Andersen, L. W., Holmberg, M. J., Berg, K. M., Donnino, M. W., \& Granfeldt, A. (2019). Inhospital cardiac arrest. JAMA, 321(12), 1200. https://doi.org/10.1001/jama.2019.1696

Bartkowiak, B., Snyder, A. M., Benjamin, A., Schneider, A., Twu, N. M., Churpek, M. M., Roggin, K. K., \& Edelson, D. P. (2019). Validating the electronic cardiac arrest risk triage (ecart) score for risk stratification of surgical inpatients in the postoperative setting. Annals of Surgery, 269(6), 1059-1063. https://doi.org/10.1097/sla.0000000000002665

Barwise, A., Thongprayoon, C., Gajic, O., Jensen, J., Herasevich, V., \& Pickering, B. W. (2016). Delayed rapid response team activation is associated with increased hospital mortality, morbidity, and length of stay in a tertiary care institution*. Critical Care Medicine, 44(1), 54-63. https://doi.org/10.1097/ccm.0000000000001346

Chan, D. (2004). Using the roy adaptation model to guide the health assessment of patients in an intensive care setting in hong kong. Connect: The World of Critical Care Nursing, 3(4), 106-110. https://doi.org/10.1891/1748-6254.3.4.106 
Dearholt, S., \& Dang, D. (2012). Johns hopkins nursing evidence based practice model and guidelines (second edition) (2nd ed.). Sigma Theta Tau International.

Haegdorens, F., Monsieurs, K. G., De Meester, K., \& Van Bogaert, P. (2020). The optimal threshold for prompt clinical review: An external validation study of the national early warning score. Journal of Clinical Nursing. https://doi.org/10.1111/jocn.15493

Holmberg, M. J., Fitzmaurice, C. E., Chan, P. S., Duval-Arnould, J., Grossestreuer, A. V., Yankama, T., Donnino, M. W., \& Andersen, L. W. (2019). Annual incidence of adult and pediatric in-hospital cardiac arrest in the united states.

https://doi.org/10.1161/CIRCOUTCOMES.119.005580

Institute of Medicine \& Committee on Quality of Health Care in America. (2000). To err is human: Building a safer health system (quality chasm) (Illustrated ed.). National Academies Press.Kivipuro, M., Tirkkonen, J., Kontula, T., Solin, J., Kalliomäki, J., Pauniaho, S.-L., Huhtala, H., Yli-Hankala, A., \& Hoppu, S. (2018). National early warning score (news) in a finnish multidisciplinary emergency department and direct vs. late admission to intensive care. Resuscitation, 128, 164-169. https://doi.org/10.1016/j.resuscitation.2018.05.020

Lee, Y., Choi, J., Park, Y., Chung, C., Park, D., Lee, J., Lee, H., \& Moon, J. (2018). Evaluation of the efficacy of the national early warning score in predicting in-hospital mortality via the risk stratification. Journal of Critical Care, 47, 222-226. https://doi.org/10.1016/j.jcrc.2018.07.011

Likosky, D. S. (2014). Clinical microsystems: A critical framework for crossing the quality chasm. PubMed Central (PMC). https://www.ncbi.nlm.nih.gov/pmc/articles/PMC4557508/ 
Medina-Lozano, E., Martín-Rodríguez, F., Castro-Villamor, M. Á., Escudero-Cuadrillero, C., Vegas, C., \& López-Izquierdo, R. (2020). Accuracy of early warning scores for predicting serious adverse events in pre-hospital traumatic injury. Injury, 51(7), 15541560. https://doi.org/10.1016/j.injury.2020.04.042

Nazarko, L. (2019). A good idea badly implemented? revised national early warning score 2 in community settings. British Journal of Community Nursing, 24(6), 291-294. https://doi.org/10.12968/bjen.2019.24.6.291

Patel, M., Jones, M., Jiggins, M., \& Williams, S. (2011). Does the use of a "track and trigger" warning system reduce mortality in trauma patients? Injury, 42(12), 1455-1459. https://doi.org/10.1016/j.injury.2011.05.030

Pimentel, M. A., Redfern, O. C., Gerry, S., Collins, G. S., Malycha, J., Prytherch, D., Schmidt, P. E., Smith, G. B., \& Watkinson, P. J. (2019). A comparison of the ability of the national early warning score and the national early warning score 2 to identify patients at risk of in-hospital mortality: A multi-centre database study. Resuscitation, 134, 147-156. https://doi.org/10.1016/j.resuscitation.2018.09.026

Prosci. (n.d.). The Prosci ADKAR Model: A Goal-Oriented Change Management Model to Guide Individual and Organizational Change. Prosci Inc. http://www.prosci.com/adkar

Razali, N. M., \& Wah, Y. B. (2011). Power comparisons of Shapiro-Wilk, KolmogorovSmirnov, Lilliefors and Anderson-Darling tests. Journal of Statistical Modeling and Analytics, 2(1), 21-33.

Royal College of Physicians. (2012). National Early Warning Score (NEWS) Standardising the assessment of acute-illness severity in the NHS. 
Silcock, D. J., Corfield, A. R., Staines, H., \& Rooney, K. D. (2019). Superior performance of national early warning score compared with quick sepsis-related organ failure assessment score in predicting adverse outcomes. European Journal of Emergency Medicine, 26(6), 433-439. https://doi.org/10.1097/mej.0000000000000589

Spångfors, M., Molt, M., \& Samuelson, K. (2020). In-hospital cardiac arrest and preceding national early warning score (news): A retrospective case-control study. Clinical Medicine, 20(1), 55-60. https://doi.org/10.7861/clinmed.2019-0137

Sylvia, M. L., \& Terhaar, M. F. (2018). Clinical analytics and data management for the DNP (2nd ed.). Springer Publishing Company.

Tan, J.-W., Zhang, X.-Q., Geng, C.-M., \& Peng, L.-L. (2020). Development of the national early warning score-calcium model for predicting adverse outcomes in patients with acute pancreatitis. Journal of Emergency Nursing, 46(2), 171-179.

https://doi.org/10.1016/j.jen.2019.11.003

The Joint Commission. (2020). Leading the way to zero. http://www.jointcommission.org/performance-improvement/jointcommission/leading$\underline{\text { the-way-to-zero }}$

Tirkkonen, J., Karlsson, S., \& Skrifvars, M. B. (2019). National early warning score (news) and the new alternative spo2 scale during rapid response team reviews: A prospective observational study. Scandinavian Journal of Trauma, Resuscitation and Emergency Medicine, 27(1). https://doi.org/10.1186/s13049-019-0691-6

West of England Academic Health Science Network. (2016). Implementing the National Early Warning Score (NEWS) [PDF]. http://www.weahsn.net 
West of England Academic Health Science Network. (2016). Implementing the national early warning score. https://www.weahsn.net 


\section{Table 1}

Budget

\section{EXPENSES}

Direct

Salary and benefits

Supplies

Services

Statistician

Indirect

Overhead

Total Expenses

Net Balance

\section{REVENUE}

Billing

N/A

$\$ 6,200.00$ Grants

N/A

$\$ 100.00$ Institutional budget support

$\$ 9,500.00$

$\$ 120.00$

$\$ 280.00$

$$
\$ 0.00
$$

$\$ 6,700.00$ Total Revenue

$\$ 9,500.00$

$\$ 2,800.00$ 


\section{Figure 1}

PRISMA Literature Search Strategy Diagram
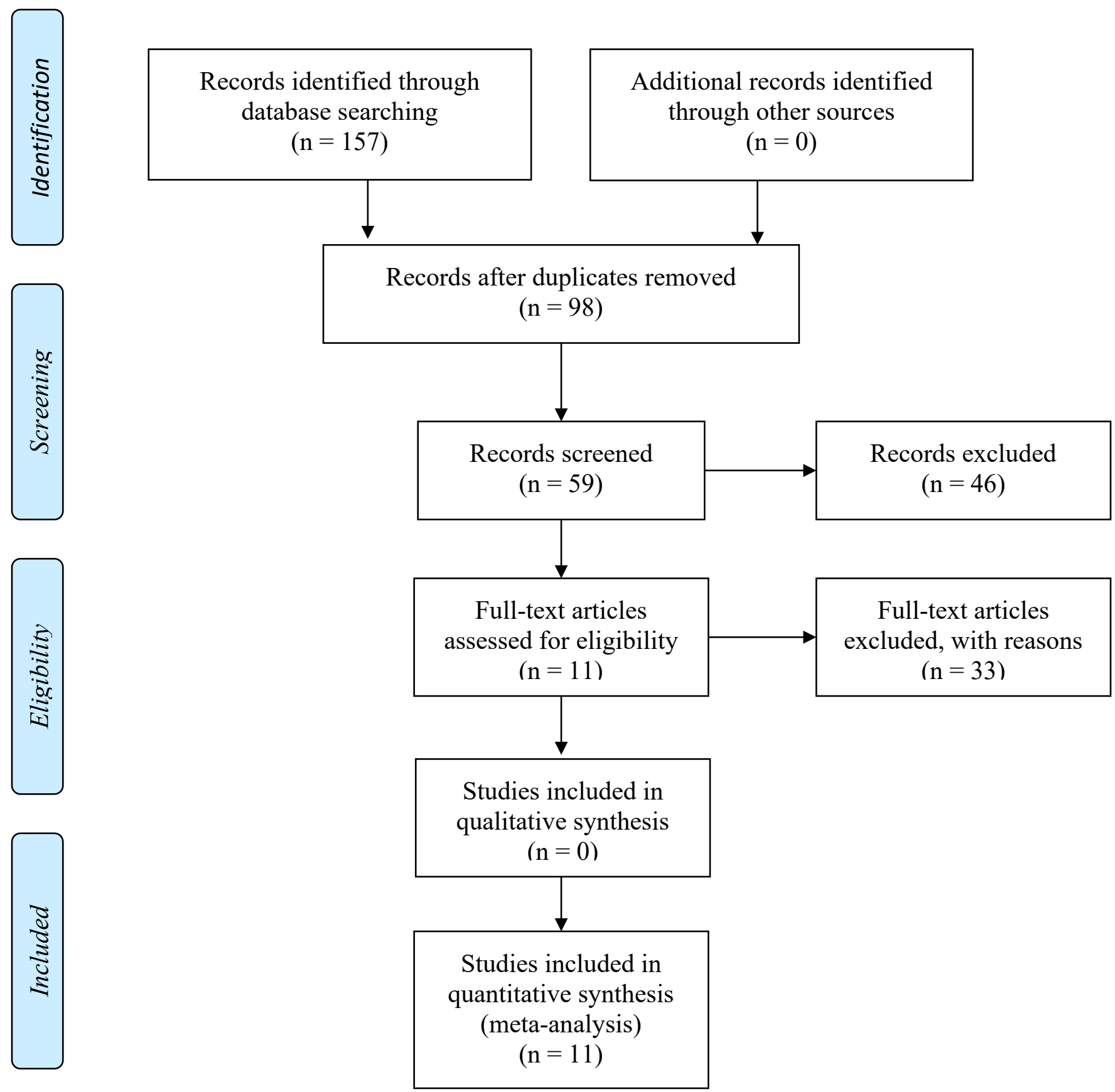

Note. Adapted from Moher, D., Liberati, A., Tetzlaff, J., \& Altman, D. G. The PRISMA Group (2009). Preferred Reporting Items for Systematic Reviews and Meta-Analyses: The PRISMA Statement. PLOS Medicine, 6(7), e1000097. https://doi.org/10.1371/journal.pmed.1000097 


\section{Figure 2}

The NEWS tool

\begin{tabular}{|c|c|c|c|c|c|c|c|}
\hline $\begin{array}{l}\text { PHYSIOLOGICAL } \\
\text { PARAMETERS }\end{array}$ & 3 & 2 & 1 & 0 & 1 & 2 & 3 \\
\hline Respiration Rate & $\leq 8$ & & $9-11$ & $12-20$ & & $21-24$ & $\geq 25$ \\
\hline $\begin{array}{l}\text { Oxygen } \\
\text { Saturations }\end{array}$ & $\leq 91$ & $92-93$ & $94-95$ & $\geq 96$ & & & \\
\hline $\begin{array}{l}\text { Any Supplemental } \\
\text { Oxygen }\end{array}$ & & Yes & & No & & & \\
\hline Temperature & $\leq 35.0$ & & $35.1-36.0$ & $36.1-38.0$ & $38.1-39.0$ & $\geq 39.1$ & \\
\hline Systolic BP & $\leq 90$ & $91-100$ & $101-110$ & $111-219$ & & & $\geq 220$ \\
\hline Heart Rate & $\leq 40$ & & $41-50$ & $51-90$ & $91-110$ & $111-130$ & $\geq 131$ \\
\hline $\begin{array}{l}\text { Level of } \\
\text { Consciousness }\end{array}$ & & & & A & & & $\mathrm{V}, \mathrm{P}$, or U \\
\hline
\end{tabular}

"The NEWS initiative flowed from the Royal College of Physicians' NEWSDIG, and was jointly developed and funded in collaboration with the Royal College of Physicians, Royal College of Nursing, National Outreach Forum and NHS Training for Innovation.

\begin{tabular}{|c|c|c|}
\hline NEWS & RISK & SUSPECT SEPSIS? \\
\hline $0-2$ & Continue monitoring Q4 & \multirow{4}{*}{$\begin{array}{c}2 \text { or more of these: } \\
\text { Temperature }<36 \text { or }>38.3 \mathrm{C} \\
\text { Heart Rate }>90 \mathrm{bpm} \\
\text { Respiratory Rate }>20 / \mathrm{min} \\
\text { WBC }>12 \text { or }<4 \\
\text { Acutely altered mental status } \\
\text { Plus new infection } \\
- \text { SEPStS }\end{array}$} \\
\hline 3-4 & $\begin{array}{l}\text { 3- THREAI! } \\
\text { Acute illness or unstable chronic disease? }\end{array}$ & \\
\hline $5-6$ & $\begin{array}{l}\text { 5- SICKI } \\
\text { Likely to deteriorate rapidly } \\
\text { Notify Provider and increase VS Q2 with NEWS }\end{array}$ & \\
\hline$\geq 7$ & $\begin{array}{l}\text { 7- NOWI } \\
\text { Immediately activate Rapid Responsel }\end{array}$ & \\
\hline
\end{tabular}

The Royal College of Physicians offers the NEWS tool as a free and open source and encourages its use for implementation of NEWS. 
Appendix A

\section{Literature Search Results}

\begin{tabular}{|c|c|c|c|c|c|c|}
\hline Citation & $\begin{array}{c}\text { Design, } \\
\text { Level } \\
\text { Quality } \\
\text { Grade }\end{array}$ & $\begin{array}{c}\text { Sample } \\
\text { Sample size }\end{array}$ & $\begin{array}{l}\text { Intervention } \\
\text { Comparison } \\
\text { (Definitions } \\
\text { should include } \\
\text { any specific } \\
\text { research tools } \\
\text { used along } \\
\text { with reliability } \\
\text { \& validity) }\end{array}$ & $\begin{array}{l}\text { Theoretical } \\
\text { Foundation }\end{array}$ & $\begin{array}{l}\text { Outcome } \\
\text { Definition }\end{array}$ & $\begin{array}{l}\text { Usefulness } \\
\text { Results } \\
\text { Key Findings }\end{array}$ \\
\hline $\begin{array}{l}\text { Bartkowiak, B., Snyder, A. M., Benjamin, A., } \\
\text { Schneider, A., Twu, N. M., Churpek, M. M., } \\
\text { Roggin, K. K., \& Edelson, D. P. (2019). } \\
\text { Validating the electronic cardiac arrest risk triage } \\
\text { (ecart) score for risk stratification of surgical } \\
\text { inpatients in the postoperative setting. Annals of } \\
\text { Surgery, 269(6), 1059-1063. } \\
\text { https://doi.org/10.1097/sla.000000000002665 } \\
\end{array}$ & $\begin{array}{l}\text { Level I, } \\
\text { Grade A }\end{array}$ & $\begin{array}{l}32,537 \\
\text { patient } \\
\text { admissions } \\
\text { were } \\
\text { analyzed } \\
\text { during this } \\
\text { study. }\end{array}$ & $\begin{array}{l}\text { Assessing the } \\
\text { accuracy by } \\
\text { comparing three } \\
\text { early warning } \\
\text { scores for } \\
\text { predicting } \\
\text { severe adverse } \\
\text { events in } \\
\text { postoperative } \\
\text { inpatients. The } \\
\text { three early } \\
\text { warning scores } \\
\text { that were } \\
\text { studied were } \\
\text { Modified Early } \\
\text { Warning Score } \\
\text { (MEWS), } \\
\text { NEWS, and the } \\
\text { electronic } \\
\text { cardiac arrest } \\
\text { risk triage score } \\
\text { (eCART). }\end{array}$ & $\begin{array}{l}\text { This was a } \\
\text { retrospective } \\
\text { cohort study. } \\
\text { A theoretical } \\
\text { framework } \\
\text { was not } \\
\text { identified. }\end{array}$ & $\begin{array}{l}\text { All three early } \\
\text { warning } \\
\text { scores were } \\
\text { significantly } \\
\text { accurate in } \\
\text { predicting } \\
\text { severe } \\
\text { adverse } \\
\text { events in } \\
\text { postoperative } \\
\text { patients. } \\
\text { eCART } \\
\text { having the } \\
\text { more accurate } \\
\text { predictability. }\end{array}$ & $\begin{array}{l}\text { Utilization of the MEWS, NEWS, or } \\
\text { eCART is an accurate way of } \\
\text { predictiting adverse event within } \\
\text { inpatient wards. }\end{array}$ \\
\hline $\begin{array}{l}\text { Patel, M., Jones, M., Jiggins, M., \& Williams, S. } \\
\text { (2011). Does the use of a "track and trigger" } \\
\text { warning system reduce mortality in trauma } \\
\text { patients? Injury, 42(12), 1455-1459. } \\
\text { https://doi.org/10.1016/j.injury.2011.05.030 }\end{array}$ & $\begin{array}{l}\text { Level I, } \\
\text { Grade B }\end{array}$ & $\begin{array}{l}\text { Admissions } \\
\text { and deaths } \\
\text { of trauma } \\
\text { patients at } \\
\text { the } \\
\text { Leicester } \\
\text { Royal }\end{array}$ & $\begin{array}{l}\text { This study } \\
\text { performed a } \\
\text { comparison test } \\
\text { pre- and post- } \\
\text { MEWS } \\
\text { implementation. } \\
\text { Student's t-test }\end{array}$ & $\begin{array}{l}\text { This is a } \\
\text { retrospective } \\
\text { study. } \\
\text { A theoretical } \\
\text { framework }\end{array}$ & $\begin{array}{l}\text { The results of } \\
\text { the study } \\
\text { found that the } \\
\text { MEWS lacks } \\
\text { sensitivity in } \\
\text { identifying }\end{array}$ & $\begin{array}{l}\text { A validated track and trigger warning } \\
\text { system is needed for early recognition } \\
\text { of physiological deterioration. A better } \\
\text { system that the MEWS needs to be } \\
\text { studied. For the tool to be effective } \\
\text { appropriate education and } \\
\text { implementation is required. }\end{array}$ \\
\hline
\end{tabular}




\begin{tabular}{|c|c|c|c|c|c|c|}
\hline & & $\begin{array}{l}\text { Infirmary } \\
\text { from } \\
\text { January } \\
2002 \text { to } \\
\text { December } \\
2009 \text { were } \\
\text { used. }\end{array}$ & $\begin{array}{l}\text { was used for } \\
\text { statistical } \\
\text { analysis. }\end{array}$ & $\begin{array}{l}\text { was not } \\
\text { identified. }\end{array}$ & $\begin{array}{l}\text { physiological } \\
\text { deterioration. }\end{array}$ & \\
\hline $\begin{array}{l}\text { Tan, J.-W., Zhang, X.-Q., Geng, C.-M., \& Peng, } \\
\text { L.-L. (2020). Development of the national early } \\
\text { warning score-calcium model for predicting } \\
\text { adverse outcomes in patients with acute } \\
\text { pancreatitis. Journal of Emergency Nursing, } \\
46(2), 171-179 . \\
\text { https://doi.org/10.1016/j.jen.2019.11.003 }\end{array}$ & $\begin{array}{l}\text { Level II, } \\
\text { Grade B }\end{array}$ & $\begin{array}{l}379 \text { patients } \\
\text { with acute } \\
\text { pancreatitis } \\
\text { admitted to } \\
\text { the } \\
\text { emergency } \\
\text { department } \\
\text { were } \\
\text { enrolled. }\end{array}$ & $\begin{array}{l}\text { Comparison of } \\
\text { the NEWS vs } \\
\text { Modified Early } \\
\text { Warning Score } \\
\text { (MEWS) vs } \\
\text { Bedside Index } \\
\text { of Severity } \\
\text { (BISAP) as } \\
\text { well as using } \\
\text { the NEWS in } \\
\text { combination } \\
\text { with calcium } \\
\text { serum testing. } \\
\text { Variables were } \\
\text { expressed as } \\
\text { medians and } \\
\text { compared using } \\
\text { the Mann- } \\
\text { Whitney } U \text { test. } \\
\text { Discrete } \\
\text { variables were } \\
\text { compared using } \\
\text { the X2 test. } \\
\text { ICU admission } \\
\text { and morality } \\
\text { were } \\
\text { determined by } \\
\text { receiver } \\
\text { operating } \\
\text { characteristics } \\
\text { curve analysis. } \\
\text { A Pearson's } \\
\text { correlation } \\
\text { analyses were } \\
\text { used to analyze } \\
\text { any } \\
\text { correlations. }\end{array}$ & $\begin{array}{l}\text { A theoretical } \\
\text { framework } \\
\text { was not } \\
\text { identified. } \\
\text { This study } \\
\text { used three } \\
\text { track and } \\
\text { trigger } \\
\text { validated } \\
\text { tools as a } \\
\text { comparison to } \\
\text { a new } \\
\text { modified } \\
\text { NEWS score } \\
\text { that included } \\
\text { calcium blood } \\
\text { test results. }\end{array}$ & $\begin{array}{l}\text { Validated } \\
\text { NEWS, } \\
\text { MEWS, and } \\
\text { BISAP with } \\
\text { predicting } \\
\text { high } \\
\text { possibility of } \\
\text { Intensive } \\
\text { Care } \\
\text { Admission. }\end{array}$ & $\begin{array}{l}\text { NEWS, MEWS, and BISAP were } \\
\text { concluded to be excellent tools for } \\
\text { early detection of deterioration of } \\
\text { patients. The NEWS-CA2+ needs } \\
\text { further studies to validate the findings } \\
\text { of the study specifically to acute } \\
\text { pancreatitis patients. }\end{array}$ \\
\hline
\end{tabular}


IMPLEMENTATION OF THE NATIONAL EARLY WARNING SCORE

\begin{tabular}{|c|c|c|c|c|}
\hline $\begin{array}{l}\text { Lee, Y., Choi, J., Park, Y., Chung, C., Park, D., } \\
\text { Lee, J., Lee, H., \& Moon, J. (2018). Evaluation of } \\
\text { the efficacy of the national early warning score in } \\
\text { predicting in-hospital mortality via the risk } \\
\text { stratification. Journal of Critical Care, } 47,222- \\
\text { 226. https://doi.org/10.1016/j.jcrc.2018.07.011 }\end{array}$ & $\begin{array}{l}\text { Level I, } \\
\text { Grade A }\end{array}$ & $\begin{array}{l}10,038 \\
\text { patients } \\
\text { were } \\
\text { screened } \\
\text { total from } \\
\text { December } \\
\text { 2013-March } \\
2014 \\
\text { inclusion } \\
\text { included } \\
\text { those } \\
\text { discharged } \\
72 \text { hours } \\
\text { after } \\
\text { admission } \\
\text { and patients } \\
\text { with } \\
\text { missing } \\
\text { variables } \\
\text { because } \\
\text { they were } \\
\text { not checked. } \\
\text { The } \\
\text { remaining } \\
1300 \\
\text { patients } \\
\text { were } \\
\text { analyzed. }\end{array}$ & $\begin{array}{l}\text { Descriptive data } \\
\text { are presented as } \\
\text { mean standard } \\
\text { deviation. An } \\
\text { independent t- } \\
\text { test was used to } \\
\text { analyze } \\
\text { categorical data } \\
\text { and a chi- } \\
\text { square test was } \\
\text { used to analyze } \\
\text { continuous } \\
\text { data. Survival } \\
\text { was calculated } \\
\text { according to the } \\
\text { trigger } \\
\text { threshold for } \\
\text { the NEWS } \\
\text { using Kaplan- } \\
\text { Meier analysis } \\
\text { and compared } \\
\text { using the log- } \\
\text { rank test. }\end{array}$ & $\begin{array}{l}\text { This was a } \\
\text { retrospective } \\
\text { observational } \\
\text { study. } \\
\text { Theoretical } \\
\text { foundation } \\
\text { was not } \\
\text { included. }\end{array}$ \\
\hline $\begin{array}{l}\text { Spångfors, M., Molt, M., \& Samuelson, K. } \\
\text { (2020). In-hospital cardiac arrest and preceding } \\
\text { national early warning score (news): A } \\
\text { retrospective case-control study. Clinical } \\
\text { Medicine, } 20(1), 55-60 . \\
\text { https://doi.org/10.7861/clinmed.2019-0137 }\end{array}$ & $\begin{array}{l}\text { Level I, } \\
\text { Grade A }\end{array}$ & $\begin{array}{l}\text { One } \\
\text { university } \\
\text { hospital and } \\
\text { two regional } \\
\text { hospitals in } \\
\text { Sweden } \\
\text { were used } \\
\text { for this } \\
\text { study. } \\
\text { All patients } \\
\text { admitted }\end{array}$ & $\begin{array}{l}\text { Researchers } \\
\text { gathered the } \\
\text { data from the } \\
\text { hospitals' } \\
\text { documentation } \\
\text { systems and } \\
\text { cardiac arrest } \\
\text { records. The } \\
\text { Mann-Whitney } \\
\text { U-test and X2 } \\
\text { test were used } \\
\text { to test for }\end{array}$ & $\begin{array}{l}\text { This is a } \\
\text { retrospective } \\
\text { multicenter } \\
\text { medical } \\
\text { record review } \\
\text { study, using a } \\
1: 2 \text { matched } \\
\text { case-control } \\
\text { design. }\end{array}$ \\
\hline
\end{tabular}

\section{Based on the}

Kaplan Meier

survival

curves,

survival times

for patients

who were

deemed high

risk using the

NEWS were

significantly

shorter.

Results of the

multivariate

Cox

proportional

hazards

regression

analysis were

used. The

study showed

a combination

of other

factors such

as age and

diagnosis in

conjunction

with the

NEWS was

effective in

predicting

hospital

mortality

Clinical

deterioration

was identified

in patients

suffering in-

hospital

cardiac arrest

with the

timespan 6-0

hours. $18 \%$ -

$24 \%$ of cases
NEWS is a simple and useful bedside

tool for predicting in-hospital

mortality. Further studies with a larger

sample size is recommended.

Use of the NEWS increases

emergency response team need.
NEWS is easy and intuitive tool for hospital staff to use in interpreting risk classification for deteriorating patients.

Easy for healthcare staff to interpret.

were 


\begin{tabular}{|c|c|c|c|c|c|c|}
\hline & & $\begin{array}{l}\text { into the } \\
\text { acute care } \\
\text { setting }>18 \\
\text { years of age } \\
\text { and } \\
\text { admitted for } \\
\text { at least }>24 \\
\text { hours } \\
\text { between } \\
\text { January } \\
20160 \\
\text { December } \\
2017 \text { were } \\
\text { included. }\end{array}$ & $\begin{array}{l}\text { differences } \\
\text { between cases } \\
\text { and excluded. } \\
\text { The Friedman } \\
\text { test was used to } \\
\text { test differences } \\
\text { between cases } \\
\text { and controls. } \\
\text { The Wilcoxon } \\
\text { signed rank test } \\
\text { was used to test } \\
\text { for differences } \\
\text { between cases } \\
\text { in difference } \\
\text { timespans. }\end{array}$ & & $\begin{array}{l}\text { classified as } \\
\text { high risk } \\
\text { whereas in the } \\
\text { timespan 6-0 } \\
\text { hours the } \\
\text { percentage } \\
\text { doubled. }\end{array}$ & \\
\hline $\begin{array}{l}\text { Ahn, J., Jung, Y., Lee, J.-R., Oh, Y., Oh, D., Huh, } \\
\text { J., Lim, C.-M., Koh, Y., \& Hong, S.-B. (2020). } \\
\text { Predictive powers of the modified early warning } \\
\text { score and the national early warning score in } \\
\text { general ward patients who activated the medical } \\
\text { emergency team. PLOS ONE, 15(5), e0233078. } \\
\text { https://doi.org/10.1371/journal.pone.0233078 }\end{array}$ & $\begin{array}{l}\text { Level I, } \\
\text { Grade B }\end{array}$ & $\begin{array}{l}\text { Adult } \\
\text { general } \\
\text { ward } \\
\text { patients in } \\
\text { retiary } \\
\text { teaching } \\
\text { hospital } \\
\text { between } \\
\text { March } 2009 \\
\text { and } \\
\text { December } \\
2016 . \\
6,729 \\
\text { medication } \\
\text { emergency } \\
\text { management } \\
\text { team } \\
\text { activations } \\
\text { were } \\
\text { analyzed. }\end{array}$ & $\begin{array}{l}\text { Comparison of } \\
\text { the MEWS and } \\
\text { the NEWS for } \\
\text { 28-day } \\
\text { mortality } \\
\text { prediction in } \\
\text { general ward } \\
\text { patient. } \\
\text { Data was used } \\
\text { as either mean } \\
\text { with standard } \\
\text { deviation or } \\
\text { median with } \\
\text { interquartile } \\
\text { range. MEWS } \\
\text { and NEWS } \\
\text { were calculated } \\
\text { with data } \\
\text { collected during } \\
\text { the emergency } \\
\text { management } \\
\text { team call. } \\
\text { Variables were } \\
\text { compared } \\
\text { between } \\
\text { patients who } \\
\text { survived } 28 \\
\text { days after } \\
\text { medical }\end{array}$ & $\begin{array}{l}\text { This is a } \\
\text { retrospective } \\
\text { cohort study. } \\
\text { A theoretical } \\
\text { framework } \\
\text { was not } \\
\text { specifically } \\
\text { identified. }\end{array}$ & $\begin{array}{l}\text { After medical } \\
\text { emergency } \\
\text { team } \\
\text { management, } \\
2,274 \text { patients } \\
\text { were } \\
\text { transferred to } \\
\text { the ICU and } \\
1,717 \text { patients } \\
\text { died within } \\
\text { 28-days. }\end{array}$ & $\begin{array}{l}\text { Both MEWS and NEWS had poor } \\
\text { predictive power for } 28 \text {-day mortality } \\
\text { in patients. While both are appropriate } \\
\text { triggers for need of emergency } \\
\text { management, that cannot predict } \\
\text { positive or negative patient outcomes. } \\
\text { Increase in rapid response and arrest } \\
\text { were noted. }\end{array}$ \\
\hline
\end{tabular}




\begin{tabular}{|c|c|c|c|c|c|c|}
\hline & & & $\begin{array}{l}\text { emergency } \\
\text { team } \\
\text { intervention and } \\
\text { those that did } \\
\text { not using the } \\
\text { Student's t-test } \\
\text { or the Mann- } \\
\text { Whitney U test } \\
\text { for continuous } \\
\text { variables and } \\
\text { the chi-square } \\
\text { test for } \\
\text { categorical } \\
\text { variables. }\end{array}$ & & & \\
\hline $\begin{array}{l}\text { Silcock, D. J., Corfield, A. R., Staines, H., \& } \\
\text { Rooney, K. D. (2019). Superior performance of } \\
\text { national early warning score compared with quick } \\
\text { sepsis-related organ failure assessment score in } \\
\text { predicting adverse outcomes. European Journal of } \\
\text { Emergency Medicine, 26(6), 433-439. } \\
\text { https://doi.org/10.1097/mej.0000000000000589 } \\
\end{array}$ & $\begin{array}{l}\text { Level I, } \\
\text { Grade A }\end{array}$ & $\begin{array}{l}1713 \\
\text { patients } \\
\text { were } \\
\text { included in } \\
\text { this study. }\end{array}$ & $\begin{array}{l}\text { The study } \\
\text { aimed to } \\
\text { compare the } \\
\text { ability for the } \\
\text { NEWS and } \\
\text { quick Sepsis- } \\
\text { related Organ } \\
\text { Failure } \\
\text { Assessment } \\
\text { Score (qSOFA) } \\
\text { to predict } \\
\text { adverse } \\
\text { outcomes in } \\
\text { patients. } \\
\text { Comparison } \\
\text { qSOFA and } \\
\text { NEWS } \\
\text { performance } \\
\text { was assessed } \\
\text { using receiver } \\
\text { ioperating } \\
\text { characteristic } \\
\text { curves using } \\
\text { DeLong's test. }\end{array}$ & $\begin{array}{l}\text { Theoretical } \\
\text { framework } \\
\text { for this study } \\
\text { was not } \\
\text { identified. }\end{array}$ & $\begin{array}{l}\text { Comparison } \\
\text { data using } \\
\text { Delong's test } \\
\text { showed } \\
\text { NEWS total } \\
\text { score to be } \\
\text { superior to } \\
\text { qSOFA at } \\
\text { predicting } \\
\text { combined } \\
\text { ICU } \\
\text { admission } \\
\text { within 48- } \\
\text { hours of } \\
\text { presentation } \\
\text { or 30-day } \\
\text { mortality. }\end{array}$ & $\begin{array}{l}\text { Results show that the NEWS is } \\
\text { superior in identifying patients at risk } \\
\text { of adverse outcomes. } \\
\text { qSofa can identify patients at risk of } \\
\text { adverse outcomes in prehospital } \\
\text { settings. }\end{array}$ \\
\hline $\begin{array}{l}\text { Pimentel, M. A., Redfern, O. C., Gerry, S., } \\
\text { Collins, G. S., Malycha, J., Prytherch, D., } \\
\text { Schmidt, P. E., Smith, G. B., \& Watkinson, P. J. } \\
\text { (2019). A comparison of the ability of the national } \\
\text { early warning score and the national early } \\
\text { warning score } 2 \text { to identify patients at risk of in- }\end{array}$ & $\begin{array}{l}\text { Level 1, } \\
\text { Grade A }\end{array}$ & $\begin{array}{l}\text { Five acute } \\
\text { hospital } \\
\text { from the } \\
\text { United } \\
\text { Kingdom } \\
\text { participated }\end{array}$ & $\begin{array}{l}\text { The aims of this } \\
\text { study were to } \\
\text { compare the } \\
\text { ability of the } \\
\text { NEWS and the } \\
\text { NEWS-2 to }\end{array}$ & $\begin{array}{l}\text { This was a } \\
\text { multi-center } \\
\text { retrospective } \\
\text { observational } \\
\text { study. }\end{array}$ & $\begin{array}{l}\text { NEWS-s } \\
\text { demonstrated } \\
\text { no } \\
\text { improvement } \\
\text { in } \\
\text { discrimination }\end{array}$ & $\begin{array}{l}\text { NEWS-2 modifications to NEWS does } \\
\text { not improve discrimination to adverse } \\
\text { outcomes in patient with documented } \\
\text { T2RF and decrease discrimination in } \\
\text { patients at risk of T2RF. }\end{array}$ \\
\hline
\end{tabular}


IMPLEMENTATION OF THE NATIONAL EARLY WARNING SCORE

\begin{tabular}{|c|c|c|c|c|c|c|}
\hline $\begin{array}{l}\text { hospital mortality: A multi-centre database study. } \\
\text { Resuscitation, 134, 147-156. } \\
\text { https://doi.org/10.1016/j.resuscitation.2018.09.026 }\end{array}$ & & $\begin{array}{l}\text { in this } \\
\text { study. } \\
251,266 \\
\text { adult } \\
\text { admissions } \\
\text { were } \\
\text { analyzed for } \\
\text { this study. }\end{array}$ & $\begin{array}{l}\text { identify patients } \\
\text { at risk of in- } \\
\text { hospital } \\
\text { mortality and } \\
\text { other adverse } \\
\text { outcomes. } \\
\text { Type II } \\
\text { respiratory } \\
\text { failure (T2RF) } \\
\text { patients were } \\
\text { analyzed for } \\
\text { discrimination } \\
\text { in NEWS vs } \\
\text { NEWS-2. } \\
\text { The NEWS and } \\
\text { NEWS-2 was } \\
\text { assessed by } \\
\text { discrimination } \\
\text { using receiver } \\
\text { operating } \\
\text { characteristics } \\
\text { (ROS) curve } \\
\text { analysis. Post- } \\
\text { hos sub- } \\
\text { analysis of } \\
\text { performance by } \\
\text { institution were } \\
\text { done. Post-hoc } \\
\text { efficiency curve } \\
\text { analysis was } \\
\text { completed. }\end{array}$ & & $\begin{array}{l}\text { over NEWS } \\
\text { for patients } \\
\text { with } \\
\text { documented } \\
\text { T2RF. }\end{array}$ & $\begin{array}{l}\text { NEWS-2 did not improve the } \\
\text { detection of adverse outcomes in } \\
\text { comparison to NEWS. } \\
\text { Hospital collaboration significant to } \\
\text { implementation for optimal patient } \\
\text { outcomes. }\end{array}$ \\
\hline $\begin{array}{l}\text { Tirkkonen, J., Karlsson, S., \& Skrifvars, M. B. } \\
\text { (2019). National early warning score (news) and } \\
\text { the new alternative spo } 2 \text { scale during rapid } \\
\text { response team reviews: A prospective } \\
\text { observational study. Scandinavian Journal of } \\
\text { Trauma, Resuscitation and Emergency Medicine, } \\
27(1) . \text { https://doi.org/10.1186/s13049-019-0691-6 }\end{array}$ & $\begin{array}{l}\text { Level 1, } \\
\text { Grade A }\end{array}$ & $\begin{array}{l}\text { A large } \\
\text { Finnish } \\
\text { university } \\
\text { tertiary } \\
\text { hospital was } \\
\text { used for this } \\
\text { two-year } \\
\text { study. The } \\
\text { final cohort } \\
\text { consisted of } \\
886\end{array}$ & $\begin{array}{l}\text { Prospective } \\
\text { data was } \\
\text { collected on all } \\
\text { rapid response } \\
\text { team } \\
\text { activations. The } \\
\text { Charlson } \\
\text { comorbidity } \\
\text { index was used } \\
\text { to describe the } \\
\text { burden of }\end{array}$ & $\begin{array}{l}\text { This was a } \\
\text { two-year } \\
\text { prospective } \\
\text { observational } \\
\text { study. } \\
\text { A theoretical } \\
\text { framework } \\
\text { was not } \\
\text { identified. }\end{array}$ & $\begin{array}{l}\text { The study } \\
\text { found that } \\
80 \% \text { of the } \\
\text { rapid } \\
\text { response team } \\
\text { calls for } \\
\text { patients had a } \\
\text { NEWS score } \\
\text { of seven or } \\
\text { more, which } \\
\text { is the key }\end{array}$ & $\begin{array}{l}\text { The NEWS predicts patient's hospital } \\
\text { outcomes not only for the initiation of } \\
\text { a rapid response call but for the } \\
\text { identification of at-risk patients for } \\
\text { adverse events. Increase in rapid } \\
\text { responses due to NEWS } \\
\text { implementation. }\end{array}$ \\
\hline
\end{tabular}




\begin{tabular}{|c|c|c|c|c|c|c|}
\hline & & $\begin{array}{l}\text { hospitalized } \\
\text { patients. } \\
1283 \text { rapid } \\
\text { response } \\
\text { team calls } \\
\text { were } \\
\text { reviewed. }\end{array}$ & $\begin{array}{l}\text { comorbidities } \\
\text { before the } \\
\text { current } \\
\text { admission. } \\
\text { Hosmer } \\
\text { Lemeshow tests } \\
\text { were conducted } \\
\text { to present the } \\
\text { goodness-of-fit } \\
\text { data for the } \\
\text { multivariate } \\
\text { models. The } \\
\text { area under the } \\
\text { receiver } \\
\text { operating } \\
\text { characteristic } \\
\text { analysis was } \\
\text { used to test the } \\
\text { discriminative } \\
\text { performance of } \\
\text { the NEWS on } \\
\text { two outcomes. }\end{array}$ & & $\begin{array}{l}\text { trigger } \\
\text { threshold for } \\
\text { emergency } \\
\text { assessment. } \\
\text { Higher } \\
\text { NEWS scores } \\
\text { were } \\
\text { associated } \\
\text { with } \\
\text { immediate } \\
\text { and in- } \\
\text { hospital } \\
\text { adverse } \\
\text { outcomes. }\end{array}$ & \\
\hline $\begin{array}{l}\text { Kivipuro, M., Tirkkonen, J., Kontula, T., Solin, J., } \\
\text { Kalliomäki, J., Pauniaho, S.-L., Huhtala, H., Yli- } \\
\text { Hankala, A., \& Hoppu, S. (2018). National early } \\
\text { warning score (news) in a finnish } \\
\text { multidisciplinary emergency department and } \\
\text { direct vs. late admission to intensive care. } \\
\text { Resuscitation, 128, 164-169. } \\
\text { https://doi.org/10.1016/j.resuscitation.2018.05.020 }\end{array}$ & $\begin{array}{l}\text { Level } 1 \\
\text { Grade C }\end{array}$ & $\begin{array}{l}\text { A cohort } \\
\text { consist of } \\
1,354 \\
\text { patients in } \\
\text { the } \\
\text { Emergency } \\
\text { Department } \\
\text { from June } \\
2015 \text { to July } \\
2015 \text {. }\end{array}$ & $\begin{array}{l}\text { Differences in } \\
\text { baseline } \\
\text { characteristics } \\
\text { between the } \\
\text { groups were } \\
\text { tested with the } \\
\text { X2 test and the } \\
\text { Mann-Whitney } \\
\text { U test the area } \\
\text { under the } \\
\text { receiver- } \\
\text { operating } \\
\text { characteristic } \\
\text { curve to assess } \\
\text { the ability of } \\
\text { the NEWS to } \\
\text { discriminate } \\
\text { between the in- } \\
\text { hospital and } 30- \\
\text { day survivors } \\
\text { and non- } \\
\text { survivors. The } \\
\text { Hosmer- }\end{array}$ & $\begin{array}{l}\text { One-month } \\
\text { prospective } \\
\text { cohort study. } \\
\\
\text { A theoretical } \\
\text { framework } \\
\text { was not } \\
\text { identified. }\end{array}$ & $\begin{array}{l}\text { Results } \\
\text { confirmed } \\
\text { that the } \\
\text { NEWS is } \\
\text { associated } \\
\text { with in- } \\
\text { hospital and } \\
\text { 30-day } \\
\text { mortality. }\end{array}$ & $\begin{array}{l}\text { Results concluded that the } \\
\text { implementation of the NEWS to } \\
\text { general wards would provide an } \\
\text { objective continuum to the } \\
\text { reassessment of patient's homeostasis } \\
\text { throughout their hospital admission. }\end{array}$ \\
\hline
\end{tabular}




\begin{tabular}{|c|c|c|c|c|c|c|}
\hline & & & $\begin{array}{l}\text { Lemeshow test } \\
\text { was conducted } \\
\text { to present the } \\
\text { goodness of-fit } \\
\text { of the models. }\end{array}$ & & & \\
\hline $\begin{array}{l}\text { Haegdorens, F., Monsieurs, K. G., De Meester, } \\
\text { K., \& Van Bogaert, P. (2020). The optimal } \\
\text { threshold for prompt clinical review: An external } \\
\text { validation study of the national early warning } \\
\text { score. Journal of Clinical Nursing. } \\
\text { https://doi.org/10.1111/jocn.15493 }\end{array}$ & $\begin{array}{l}\text { Level 1, } \\
\text { Grade A }\end{array}$ & $\begin{array}{l}1,523 \text { cross- } \\
\text { sectional } \\
\text { samples } \\
\text { were used. } \\
\text { A total of } \\
390 \text { patients } \\
\text { in serious } \\
\text { adverse } \\
\text { event were } \\
\text { sampled. } \\
\text { Six Belgium } \\
\text { acute } \\
\text { hospitals } \\
\text { were used. }\end{array}$ & $\begin{array}{l}\text { The aim of the } \\
\text { study was to } \\
\text { validate the } \\
\text { NEWS. } \\
\text { Two sample } \\
\text { groups were } \\
\text { selected. }\end{array}$ & $\begin{array}{l}\text { This was an } \\
\text { external } \\
\text { validation } \\
\text { study using } \\
\text { retrospective } \\
\text { data. Two- } \\
\text { sided Fisher } \\
\text { exact tests } \\
\text { were used to } \\
\text { compare the } \\
\text { proportion of } \\
\text { reached } \\
\text { outcomes } \\
\text { between } \\
\text { positive and } \\
\text { negative } \\
\text { NEWS } \\
\text { scores. } \\
\text { Pearson's chi- } \\
\text { squared tests } \\
\text { were used to } \\
\text { compare all } \\
\text { proportions of } \\
\text { characteristics } \\
\text { between the } \\
\text { cross- } \\
\text { sectional } \\
\text { samples. } \\
\text { Mann- } \\
\text { Whitney U } \\
\text { test were used } \\
\text { to compare } \\
\text { NEWS } \\
\text { values. }\end{array}$ & $\begin{array}{l}\text { The NEWS is } \\
\text { a track-and- } \\
\text { trigger system } \\
\text { aimed } \\
\text { towards } \\
\text { support } \\
\text { nurses and } \\
\text { physicians in } \\
\text { detecting and } \\
\text { responding to } \\
\text { deterioration } \\
\text { in } \\
\text { hospitalized } \\
\text { patients. }\end{array}$ & $\begin{array}{l}\text { Results validated the NEWS to be } \\
\text { applied in general hospital wards. }\end{array}$ \\
\hline
\end{tabular}


Appendix B

Strengths Weakness Opportunities and Threats Analysis

\section{Internal Forces (Project)}

\section{Strengths (Internal)}

- National leadership support

- Local leadership support

- Education department support

- Quality, Safety, \& Value department support

- Existing technology supports the NEWS

\section{Weaknesses (Internal)}

- Absence of a standards of process

- Lack of training computer labs

- Pulling nurses from patient care

- Poor hospital layout

\section{External Forces (Organization or Environment)}

\section{Opportunities (External)}

- Training can be scheduled virtually

- National networking with other hospital that have implemented NEWS

- Decrease hospital length of stay

- Decrease possibility of sentinel events

- Hospital cost savings

\section{Threats (External)}

- COVID-19: if surge rises, change projects will be placed on hold

- Staff turnover

- Unplanned leave

- Hospital system changing to different track and trigger tool 
Appendix C

\section{Project Schedule}

\begin{tabular}{|c|c|c|c|c|c|c|c|c|c|c|c|c|c|c|c|c|c|c|c|c|c|c|c|c|}
\hline & \multicolumn{8}{|c|}{ NUR7801 } & \multicolumn{8}{|c|}{ NUR7802 } & \multicolumn{8}{|c|}{ NUR7803 } \\
\hline 忿 & $\frac{7}{\sqrt{0}}$ & $\begin{array}{l}\frac{m}{\mathrm{~d}} \\
\frac{\pi}{3}\end{array}$ & $\frac{n}{2}$ & $\frac{5}{3}$ & $\frac{9}{8}$ & $\begin{array}{l}= \\
y \\
0 \\
3\end{array}$ & $\begin{array}{l}\frac{m}{4} \\
\frac{y}{8} \\
3\end{array}$ & $\begin{array}{l}n \\
\frac{n}{2} \\
3 \\
3\end{array}$ & $\begin{array}{l}-7 \\
\frac{y}{0} \\
3\end{array}$ & $\begin{array}{l}m \\
\frac{1}{2} \\
\frac{2}{3}\end{array}$ & $\begin{array}{l}n \\
\frac{4}{0} \\
3 \\
3\end{array}$ & $\frac{5}{2}$ & $\frac{a}{3}$ & $\begin{array}{l}\beth \\
\frac{y}{0} \\
3\end{array}$ & $\begin{array}{l}\frac{m}{4} \\
\frac{\pi}{3} \\
3\end{array}$ & $\begin{array}{l}n \\
\frac{n}{0} \\
3 \\
3\end{array}$ & $\frac{7}{4}$ & $\begin{array}{l}m \\
\frac{n}{0} \\
3 \\
3\end{array}$ & $\frac{n}{8}$ & $\frac{\bar{y}}{3}$ & $\begin{array}{l}\frac{9}{8} \\
\frac{0}{3}\end{array}$ & $\begin{array}{l}= \\
y \\
\frac{y}{0} \\
3\end{array}$ & $\begin{array}{l}\frac{m}{4} \\
\frac{y}{0} \\
3\end{array}$ & $\frac{n}{4}$ \\
\hline Meet with preceptor & & & & & & & & & & & & & & & & & & & & & & & & \\
\hline $\begin{array}{l}\text { Prepare project } \\
\text { proposal }\end{array}$ & & & & & & & & & & & & & & & & & & & & & & & & \\
\hline $\begin{array}{l}\text { Review IRB proposal } \\
\text { approval process }\end{array}$ & & & & & & & & & & & & & & & & & & & & & & & & \\
\hline $\begin{array}{l}\text { Collect \& complete } \\
\text { IRB } \\
\text { documents/signatures }\end{array}$ & & & & & & & & & & & & & & & & & & & & & & & & \\
\hline Submit the proposal & & & & & & & & & & & & & & & & & & & & & & & & \\
\hline $\begin{array}{l}\text { Generate awareness \& } \\
\text { celebrate } \\
\text { achievements }\end{array}$ & & & & & & & & & & & & & & & & & & & & & & & & \\
\hline $\begin{array}{l}\text { Preparing training } \\
\text { materials }\end{array}$ & & & & & & & & & & & & & & & & & & & & & & & & \\
\hline Create SOP & & & & & & & & & & & & & & & & & & & & & & & & \\
\hline $\begin{array}{l}\text { Ensure NEWS } \\
\text { template is embedded } \\
\text { into CPRS }\end{array}$ & & & & & & & & & & & & & & & & & & & & & & & & \\
\hline $\begin{array}{l}\text { Submit to facility IRB } \\
\text { \& USA approval }\end{array}$ & & & & & & & & & & & & & & & & & & & & & & & & \\
\hline $\begin{array}{l}\text { Project schedule } \\
\text { shared with } \\
\text { stakeholders }\end{array}$ & & & & & & & & & & & & & & & & & & & & & & & & \\
\hline $\begin{array}{l}\text { Receive facility SOP } \\
\text { approval }\end{array}$ & & & & & & & & & & & & & & & & & & & & & & & & \\
\hline $\begin{array}{l}\text { Begin implementation } \\
\text { and celebrate } \\
\text { beginning of project }\end{array}$ & & & & & & & & & & & & & & & & & & & & & & & & \\
\hline $\begin{array}{l}\text { Education and training } \\
\text { to nursing staff }\end{array}$ & & & & & & & & & & & & & & & & & & & & & & & & \\
\hline $\begin{array}{l}\text { Chart audit with } \\
\text { feedback and remedial } \\
\text { training }\end{array}$ & & & & & & & & & & & & & & & & & & & & & & & & \\
\hline Data collection & & & & & & & & & & & & & & & & & & & & & & & & \\
\hline Evaluation & & & & & & & & & & & & & & & & & & & & & & & & \\
\hline Project closure & & & & & & & & & & & & & & & & & & & & & & & & \\
\hline
\end{tabular}




\section{Appendix D}

Data Collection Tools

Code Blue and Rapid Response Calls Pre-Intervention

\begin{tabular}{|c|c|c|c|c|c|c|c|c|c|c|c|c|c|c|c|c|}
\hline 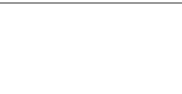 & $\begin{array}{c}\text { Week } \\
1\end{array}$ & $\begin{array}{c}\text { Week } \\
2\end{array}$ & $\begin{array}{c}\text { Week } \\
\mathbf{3}\end{array}$ & $\begin{array}{c}\text { Week } \\
4\end{array}$ & $\begin{array}{c}\text { Week } \\
5\end{array}$ & $\begin{array}{c}\text { Week } \\
6\end{array}$ & $\begin{array}{c}\text { Week } \\
7\end{array}$ & $\begin{array}{l}\text { Week } \\
8\end{array}$ & $\begin{array}{c}\text { Week } \\
9\end{array}$ & $\begin{array}{c}\text { Week } \\
10\end{array}$ & $\begin{array}{c}\text { Week } \\
11\end{array}$ & $\begin{array}{c}\text { Week } \\
12\end{array}$ & $\begin{array}{c}\text { Week } \\
13\end{array}$ & $\begin{array}{c}\text { Week } \\
14\end{array}$ & $\begin{array}{c}\text { Week } \\
15\end{array}$ & Total \\
\hline $\begin{array}{l}\text { \# Of Code } \\
\text { Blue Calls }\end{array}$ & 5 & 3 & 3 & 2 & 2 & 0 & 0 & 4 & 2 & 0 & 0 & 0 & 4 & 5 & 1 & 31 \\
\hline $\begin{array}{c}\text { \# Of Rapid } \\
\text { Responses }\end{array}$ & 5 & 2 & 4 & 9 & 7 & 6 & 2 & 5 & 7 & 2 & 7 & 1 & 6 & 2 & 1 & 66 \\
\hline
\end{tabular}

Post Intervention

\begin{tabular}{|c|c|c|c|c|c|c|c|c|c|c|c|c|c|c|c|c|}
\hline 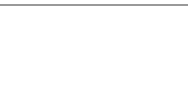 & $\begin{array}{c}\text { Week } \\
1\end{array}$ & $\begin{array}{c}\text { Week } \\
2\end{array}$ & $\begin{array}{c}\text { Week } \\
3\end{array}$ & $\begin{array}{c}\text { Week } \\
4\end{array}$ & $\begin{array}{c}\text { Week } \\
5\end{array}$ & $\begin{array}{c}\text { Week } \\
6\end{array}$ & $\begin{array}{c}\text { Week } \\
7\end{array}$ & $\begin{array}{l}\text { Week } \\
8\end{array}$ & $\begin{array}{c}\text { Week } \\
9\end{array}$ & $\begin{array}{c}\text { Week } \\
10\end{array}$ & $\begin{array}{c}\text { Week } \\
11\end{array}$ & $\begin{array}{c}\text { Week } \\
12\end{array}$ & $\begin{array}{c}\text { Week } \\
13\end{array}$ & $\begin{array}{c}\text { Week } \\
14\end{array}$ & $\begin{array}{c}\text { Week } \\
15\end{array}$ & Total \\
\hline $\begin{array}{l}\text { \# Of Code } \\
\text { Blue Calls }\end{array}$ & 0 & 1 & 3 & 0 & 5 & 0 & 2 & 1 & 2 & 4 & 3 & 2 & 0 & 1 & 1 & 26 \\
\hline $\begin{array}{c}\text { \# Of Rapid } \\
\text { Responses }\end{array}$ & 2 & 0 & 8 & 8 & 4 & 5 & 5 & 6 & 5 & 3 & 7 & 9 & 8 & 9 & 10 & 92 \\
\hline
\end{tabular}

NEWS Score Compliance

\begin{tabular}{|c|c|c|}
\hline Date & Disposition & Code Blue / Rapid Response \\
\hline $\mathbf{2 / 2 6 / 2 0 2 1}$ & $\mathrm{N} 4$ & Rapid Response \\
\hline $\mathbf{2} / \mathbf{2 7 / 2 0 2 1}$ & $\mathrm{S} 8$ & Code Blue \\
\hline $\mathbf{2} / \mathbf{2 8 / 2 0 2 1}$ & $\mathrm{S} 10$ & Code Blue \\
\hline $\mathbf{3 / 3 / 2 0 2 1}$ & $\mathrm{S} 8$ & Code Blue \\
\hline $\mathbf{3 / 4 / 2 0 2 1}$ & $\mathrm{N} 4$ & Rapid Response \\
\hline $\mathbf{3 / 4 / 2 0 2 1}$ & $\mathrm{DOU}$ & Rapid Response \\
\hline $\mathbf{3 / 5} / \mathbf{2 0 2 1}$ & $\mathrm{T} 2$ & Rapid Response \\
\hline $\mathbf{3 / 6 / 2 0 2 1}$ & $\mathrm{CCCU}$ & Code Blue \\
\hline $\mathbf{3 / 6 / 2 0 2 1}$ & $\mathrm{CCCU}$ & Code Blue \\
\hline $\mathbf{3 / 6 / 2 0 2 1}$ & $\mathrm{N} 4$ & Code Blue \\
\hline
\end{tabular}




\begin{tabular}{|c|c|c|c|}
\hline $3 / 6 / 2021$ & DOU & Rapid Response & 1 \\
\hline $3 / 6 / 2021$ & DOU & Rapid Response & 2 \\
\hline $3 / 6 / 2021$ & CCCU & Code Blue & 3 \\
\hline $3 / 6 / 2021$ & S8 & Code Blue & 2 \\
\hline $3 / 8 / 2021$ & $\mathrm{~N} 4$ & Rapid Response & 1 \\
\hline $3 / 8 / 2021$ & N4 & Rapid Response & 1 \\
\hline $3 / 10 / 221$ & DOU & Rapid Response & 1 \\
\hline $3 / 11 / 2021$ & DOU & Rapid Response & 2 \\
\hline 3/13/2021 & S8 & Rapid Response & 2 \\
\hline $3 / 13 / 2021$ & N4 & Rapid Response & 1 \\
\hline $3 / 13 / 2021$ & N4 & Rapid Response & 2 \\
\hline $3 / 14 / 2021$ & $\mathrm{~S} 8$ & Rapid Response & 2 \\
\hline $3 / 15 / 2021$ & N4 & Code Blue & 2 \\
\hline $3 / 15 / 2021$ & N4 & Rapid Response & 2 \\
\hline $3 / 16 / 2021$ & $\mathrm{CCCU}$ & Code Blue & 2 \\
\hline $3 / 17 / 2021$ & CCCU & Code Blue & 2 \\
\hline $3 / 17 / 2021$ & S8 & Rapid Response & 2 \\
\hline $3 / 17 / 2021$ & S10 & Rapid Response & 2 \\
\hline $3 / 19 / 2021$ & CCCU & Code Blue & 2 \\
\hline $3 / 19 / 2021$ & $\mathrm{CCCU}$ & Code Blue & 2 \\
\hline $3 / 20 / 2021$ & N4 & Rapid Response & 2 \\
\hline $3 / 21 / 2021$ & DOU & Code Blue & 2 \\
\hline $3 / 24 / 2021$ & CCCU & Code Blue & 3 \\
\hline $3 / 24 / 2021$ & DOU & Code Blue & 2 \\
\hline $3 / 29 / 2021$ & N4 & Rapid Response & 2 \\
\hline $3 / 29 / 2021$ & S10 & Rapid Response & 2 \\
\hline $3 / 29 / 2021$ & $\mathrm{~N} 4$ & Rapid Response & 2 \\
\hline $4 / 1 / 2021$ & $\mathrm{~S} 8$ & Rapid Response & 2 \\
\hline $4 / 3 / 2021$ & N4 & Rapid Response & 2 \\
\hline $4 / 5 / 2021$ & DOU & Code Blue & 2 \\
\hline $4 / 5 / 2021$ & CCCU & Code Blue & 3 \\
\hline $4 / 7 / 2021$ & DOU & Rapid Response & 2 \\
\hline
\end{tabular}




\begin{tabular}{|c|c|c|c|}
\hline $4 / 7 / 2021$ & $\mathrm{~S} 10$ & Rapid Response & 2 \\
\hline $4 / 9 / 2021$ & N4 & Rapid Response & 2 \\
\hline $4 / 10 / 2021$ & S8 & Rapid Response & 2 \\
\hline $4 / 10 / 2021$ & N4 & Rapid Response & 2 \\
\hline $4 / 11 / 2021$ & $\mathrm{~S} 10$ & Rapid Response & 2 \\
\hline $4 / 12 / 2021$ & $\mathrm{~N} 4$ & Rapid Response & 2 \\
\hline $4 / 12 / 2021$ & S8 & Rapid Response & 2 \\
\hline $4 / 13 / 2021$ & DOU & Code Blue & 3 \\
\hline $4 / 16 / 2021$ & DOU & Rapid Response & 2 \\
\hline $4 / 16 / 2021$ & $\mathrm{~S} 10$ & Rapid Response & 2 \\
\hline $4 / 17 / 2021$ & N4 & Rapid Response & 2 \\
\hline $4 / 18 / 2021$ & $\mathrm{CCU}$ & Code Blue & 3 \\
\hline $4 / 18 / 2021$ & N4 & Rapid Response & 2 \\
\hline $4 / 20 / 2021$ & $\mathrm{CCU}$ & Code Blue & 3 \\
\hline $4 / 21 / 2021$ & DOU & Rapid Response & 2 \\
\hline $4 / 21 / 2021$ & DOU & Rapid Response & 2 \\
\hline $4 / 22 / 2021$ & N4 & Rapid Response & 2 \\
\hline $4 / 24 / 2021$ & $\mathrm{CCU}$ & Code Blue & 3 \\
\hline $4 / 24 / 2021$ & S8 & Code Blue & 2 \\
\hline $4 / 24 / 2021$ & $\mathrm{~S} 10$ & Rapid Response & 2 \\
\hline $4 / 24 / 2021$ & $\mathrm{CCU}$ & Code Blue & 3 \\
\hline $4 / 25 / 2021$ & DOU & Code Blue & 2 \\
\hline $4 / 25 / 2021$ & $\mathrm{CCU}$ & Code Blue & 3 \\
\hline $4 / 25 / 2021$ & N4 & Rapid Response & 2 \\
\hline $4 / 28 / 2021$ & N4 & Rapid Response & 2 \\
\hline $4 / 28 / 2021$ & $\mathrm{CCU}$ & Code Blue & 3 \\
\hline $4 / 29 / 2021$ & $\mathrm{CCU}$ & Code Blue & 3 \\
\hline $4 / 30 / 2021$ & N4 & Rapid Response & 2 \\
\hline $5 / 2 / 2021$ & DOU & Rapid Response & 2 \\
\hline $5 / 3 / 2021$ & DOU & Rapid Response & 2 \\
\hline $5 / 4 / 2021$ & $\mathrm{CCU}$ & Code Blue & 3 \\
\hline $5 / 4 / 2021$ & S8 & Rapid Response & 2 \\
\hline
\end{tabular}




\begin{tabular}{|c|c|c|c|}
\hline $5 / 5 / 2021$ & N4 & Rapid Response & 2 \\
\hline $5 / 5 / 2021$ & DOU & Code Blue & 3 \\
\hline $5 / 6 / 2021$ & N4 & Rapid Response & 2 \\
\hline $5 / 7 / 2021$ & $\mathrm{CCU}$ & Code Blue & 3 \\
\hline $5 / 8 / 2021$ & DOU & Rapid Response & 2 \\
\hline $5 / 8 / 2021$ & DOU & Rapid Response & 2 \\
\hline $5 / 9 / 2021$ & $\mathrm{~N} 4$ & Rapid Response & 1 \\
\hline $5 / 9 / 2021$ & N4 & Rapid Response & 1 \\
\hline $5 / 10 / 2021$ & S8 & Rapid Response & 2 \\
\hline $5 / 10 / 2021$ & $\mathrm{CCU}$ & Code Blue & 3 \\
\hline $5 / 11 / 2021$ & N4 & Rapid Response & 2 \\
\hline $5 / 11 / 2021$ & N4 & Rapid Response & 2 \\
\hline $5 / 11 / 2021$ & DOU & Rapid Response & 2 \\
\hline $5 / 14 / 2021$ & DOU & Rapid Response & 2 \\
\hline $5 / 14 / 2021$ & DOU & Rapid Response & 2 \\
\hline $5 / 14 / 2021$ & $\mathrm{CCU}$ & Code Blue & 3 \\
\hline $5 / 15 / 2021$ & DOU & Rapid Response & 2 \\
\hline $5 / 19 / 2021$ & DOU & Rapid Response & 2 \\
\hline $5 / 20 / 2021$ & N4 & Rapid Response & 2 \\
\hline $5 / 20 / 2021$ & N4 & Rapid Response & 2 \\
\hline $5 / 20 / 2021$ & S10 & Rapid Response & 1 \\
\hline $5 / 21 / 2021$ & $\mathrm{~N} 4$ & Rapid Response & 2 \\
\hline $5 / 22 / 2021$ & N4 & Rapid Response & 2 \\
\hline $5 / 22 / 2021$ & DOU & Rapid Response & 2 \\
\hline $5 / 22 / 2021$ & DOU & Rapid Response & 2 \\
\hline $5 / 23 / 2021$ & N4 & Rapid Response & 2 \\
\hline $5 / 23 / 2021$ & $\mathrm{~N} 4$ & Rapid Response & 2 \\
\hline $5 / 24 / 2021$ & S10 & Rapid Response & 2 \\
\hline $5 / 25 / 2021$ & N4 & Rapid Response & 2 \\
\hline $5 / 25 / 2021$ & $\mathrm{CCU}$ & Code Blue & 3 \\
\hline $5 / 27 / 2021$ & S8 & Rapid Response & 2 \\
\hline $5 / 28 / 2021$ & N4 & Rapid Response & 2 \\
\hline
\end{tabular}




\begin{tabular}{|l|l|l|l|}
\hline $\mathbf{5} / \mathbf{2 9} / \mathbf{2 0 2 1}$ & S10 & Rapid Response & 2 \\
\hline $\mathbf{5 / 2 9 / 2 0 2 1}$ & DOU & Rapid Response & 2 \\
\hline $\mathbf{5 / 2 9 / 2 0 2 1}$ & DOU & Rapid Response & 2 \\
\hline
\end{tabular}


Table 3

Appendix E

Two-Tailed Paired Samples t-Test for the Difference Between Number of Code Blue Calls Pre and Post Intervention

\begin{tabular}{|c|c|c|c|c|c|c|}
\hline \multicolumn{2}{|c|}{ Number of Code Blue Calls Pre Intervention } & \multicolumn{2}{|c|}{ Number of Code Blue Calls Post Intervention } & \multirow[b]{2}{*}{$t$} & \multirow[b]{2}{*}{$p$} & \multirow[b]{2}{*}{$d$} \\
\hline$M$ & $S D$ & $M$ & $S D$ & & & \\
\hline 2.07 & 1.87 & 1.67 & 1.54 & 0.54 & .595 & 0.14 \\
\hline
\end{tabular}

Note. $\mathrm{N}=15$. Degrees of Freedom for the $t$-statistic $=14 . d$ represents Cohen's $d$.

Figure 3

The means of Number of code blue calls Pre and Post Intervention 


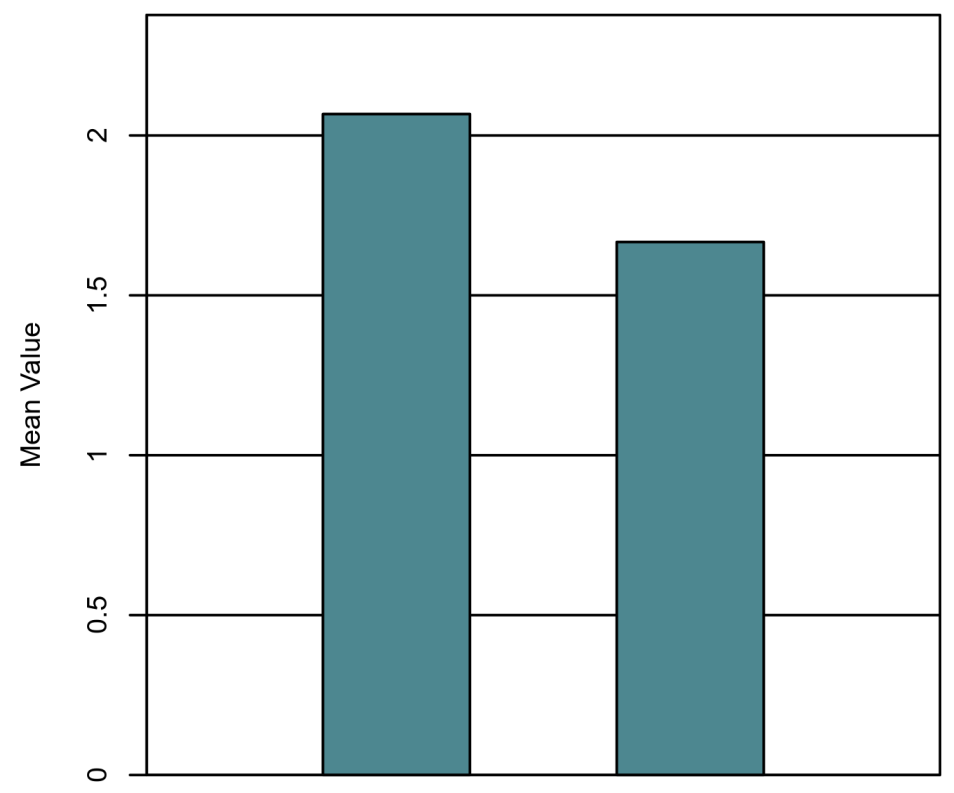

Number_of_Code_Blue_Calls_Pre_Intervention

\section{Table 4}

Two-Tailed Paired Samples t-Test for the Difference Between Number of Rapid Responses Pre and Post Intervention

Number of Rapid Response Calls Pre Intervention Number of Rapid Response Calls Post Intervention

$M$

4.40
$S D$

2.59
$M$

5.93
$S D$

2.87 $t \quad p \quad d$

$\begin{array}{lll}-1.51 & .154 & 0.39\end{array}$

Note. $\mathrm{N}=15$. Degrees of Freedom for the $t$-statistic $=14 . d$ represents Cohen's $d$. 


\section{Figure 4}

The means of Number of Rapid Responses Pre and Post Intervention

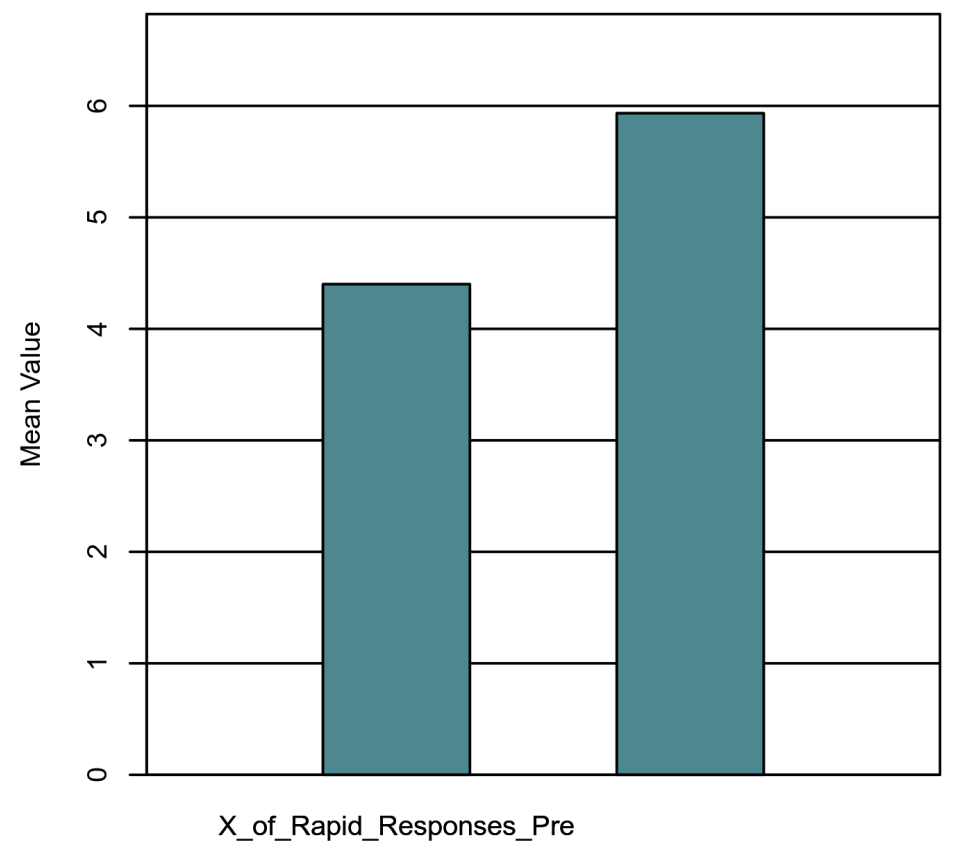

Table 5

Frequency Table for Nominal Variables

\begin{tabular}{lc}
\hline Variable & Rapid Response Code Blue \\
Respond Appropriately &
\end{tabular}


Yes

$65(88 \%)$

No

$9(12 \%)$

$33(97 \%)$

Missing

$0(0 \%)$

$1(3 \%)$

$0(0 \%)$

Note. Due to rounding errors, column wise percentages may not equal $100 \%$. 